\title{
PERLINDUNGAN HUKUM BAGI ANAK KORBAN PERKOSAAN DALAM PERADILAN ANAK
}

Oleh :

\author{
H. Dudung Mulyadi, S.H., M.H. ${ }^{*}$ \\ dudungmulyadi67@gmail.com
}

\begin{abstract}
Research shows that minors who are physically, mentally and socially vulnerable are vulnerable to becoming victims of rape crime. Article 287 of the Criminal Code has not fully protected the rights of children who are victims of rape, because the threat of criminal sanctions in this article is still very mild, causing rape perpetrators to be only punished lightly and even free from punishment. The birth of Article 81 (2) of the Law of the Republic of Indonesia Number 35 of 2014 concerning Amendments to Law Number 23 of 2002 concerning Child Protection provides more promising hope for children who are victims of rape to get protection. This article has had the threat of severe criminal sanctions and uses a minimum limit so that the perpetrator cannot be free from prosecution. It's just that in the Law of the Republic of Indonesia Number 35 of 2014 concerning Amendments to Law Number 23 of 2002 concerning Child Protection, there has been no cumulative punishment if the rape perpetrator has committed multiple rapes against children. Protection of children who are victims of rape is a shared responsibility between family, community and government. Children become victims of rape need to get legal protection in order to develop truth, justice and welfare.
\end{abstract}

Keywords : Legal Protection, Children of Rape Victims

\section{ABSTRAK}

Penelitian menunjukkan bahwa anak dibawah umur yang termasuk golongan lemah fisik, mental, dan sosial sangat rentan untuk menjadi korban kejahatan perkosaan. Pasal $287 \mathrm{KUHP}$ belum sepenuhnya melindungi hak-hak anak yang menjadi korban perkosaan, dikarenakan ancaman sanksi pidana pada pasal ini masih sangat ringan sehingga menyebabkan pelaku perkosaan hanya dihukum ringan bahkan bebas dari hukuman. Lahirnya pasal 81 (2) Undang-Undang Republik Indonesia Nomor 35 Tahun 2014 Tentang Perubahan Atas Undang-Undang Nomor 23 Tahun 2002 Tentang Perlindungan Anak memberikan harapan yang lebih menjanjikan bagi anak yang menjadi korban perkosaan untuk mendapatkan perlindungan. Pasal ini telah memiliki ancaman sanksi pidana yang cukup berat dan menggunakan batas minimal sehingga pelaku tidak dapat bebas dari tuntutan.

*) Dosen Tetap Fakultas Hukum Universitas Galuh 
Hanya saja dalam Undang-Undang Republik Indonesia Nomor 35 Tahun 2014 Tentang Perubahan Atas Undang-Undang Nomor 23 Tahun 2002 Tentang Perlindungan Anak, belum terdapat hukuman secara kumulatif bilamana pelaku perkosaan telah melakukan beberapa kali perkosaan terhadap anak-anak. Perlindungan anak yang menjadi korban perkosaan adalah tanggung jawab bersama antara keluarga, masyarakat dan pemerintah. Anak menjadi korban perkosaan perlu mendapatkan perlindungan hukum dalam rangka mengembangkan kebenaran, keadilan dan kesejahteraan.

Kata Kunci : Perlindungan Hukum, Anak Korban Perkosaan.

\section{PENDAHULUAN}

Masalah Kekerasan seksual di Indonesia, khususnya terhadap anak perlu mendapat perhatian lebih intensif dan serius lagi. Hal ini mengingat, terdapat kecenderungan bahwa korban anak sering terabaikan oleh lembagalembaga kompeten dalam sistem peradilan pidana, yang seharusnya memberikan perhatian dan perlindungan yang cukup berdasarkan hukum. Hal tersebut tidak seharusnya terjadi, sebab bagaimanapun korban tetap mempunyai hak untuk diperlakukan adil dan dilindungi hak-haknya sebagaimana didasarkan pada Pasal 28 Undang-Undang Dasar Negara Republik Indonesia Tahun 1945, beserta perubahannya Pasal 28 G ayat (1) Undang-Undang Dasar Negara Republik Indonesia Tahun 1945 menentukan bahwa "Setiap orang berhak atas perlindungan diri pribadi, keluarga, kehormatan, martabat dan harta benda yang dibawah kekuasaannya, serta berhak atas rasa aman dan perlindungan dari ancaman ketakutan untuk berbuat atau tidak berbuat atau tidak berbuat sesuatu yang merupakan hak asasi".

Pasal $28 \mathrm{H}$ ayat (2) Undang-Undang Dasar Negara Republik Indonesia Tahun 1945 menentukan bahwa "Setiap orang berhak mendapat kemudahan dan perlakuan khusus untuk memperoleh kesempatan dan manfaat yang sama guna untuk memperoleh kesempatan dan manfaat yang sama guna mencapai persamaan dan keadilan.

Akhir-akhir ini intensitas kekerasan terhadap anak semakin meningkat. Adanya berbagai tindak kekerasan menciptakan korban anak dalam jumlah yang cukup banyak. Akibat adanya berbagai tindak kekerasan, anak 
mengalami gangguan perkembangan baik secara fisik maupun secara psikologi.

Anak yang menjadi korban perkosaan atau keluarganya, kerap kali tidak tahu apa yang harus dikerjakan atau seganmengusahakan penyelesaian permasalahan itu, karena kurang/ tidak mempunyai pengetahuan, dana, keberanian, dan harapan. Mungkin juga karena adanya anggapan bahwa kejahatan perkosaan yang menimpa diri anak sudah nasibnya. Orang tua dari anak yang menjadi korban perkosaan sering merasa malu jika diketahui bahwa anaknya diperkosa sehingga mereka tidak melapor dan segan menangani permasalahan secara tuntas. Anak korban pemerkosaan benarbenar memerlukan perlindungan hukum, pelayanan dan pendamping mental, fisik, social dalam mengatasi penderitaannya.

Pasal 287 Kitab Undang-Undang Hukum Pidana (KUHP) belum sepenuhnya melindungi hak-hak anak yang menjadi korban perkosaan, dikarenakan ancaman sanksi pidana pada pasal ini masih sangat ringan sehingga menyebabkan pelaku perkosaan hanya dihukum ringan bahkan bebas dari hukuman, terlebih bilamana pelaku perkosaan telah melakukan lima kali perkosaan terhadap anak-anak dan hanya dihukum pada satu kasus perkosaan.

Sudah saatnya tindak kejahatan pemerkosaan terhadap anak ini menjadi sesuatu yang patut mendapatkan perhatian. Sebab telah diketahui bersama bahwa anak adalah generasi penerus dan masa depan dari suatu bangsa. Anak adalah bagian yang tak terpisahkan dari kehidupan manusia yang selayaknya mempunyai hak untuk dilindungi dan mendapatkan kesejahteraan hidup.

Untuk lebih memfokuskan pembahasan dalam tulisan ini, terdapat tiga rumusan masalah yang dapat diidentifikasi, yaitu: 1) faktor-faktor apa sajakah yang menyebabkan terjadinya perkosaan terhadap anak di bawah umur ? 2) bagaimanakah upaya perlindungan hukum terhadap anak yang menjadi korban kejahatan perkosaan? 3) bagaimana penerapan Sanksi Pidana bagi pelaku kejahatan pemerkosaan terhadap anak di bawah umur dalam Peradilan Anak? 


\section{PEMBAHASAN}

\subsection{Faktor-Faktor Penyebab Terjadinya Kejahatan Perkosaan}

Kejahatan perkosaan dalam hal ini perkosaan terhadap anak di bawah umur dapat terjadi karena bertemunya faktor internal dan external baik dari pihak pelaku maupun pihak korban.

Faktor internal adalah faktor yang terdapat pada diri seorang pelaku maupun korban pada kasus perkosaan, misalnya sikap dan tindakan korban yang menyebabkan rangsangan sehingga pelaku terpancing untuk melakukan perkosaan terhadap diri korban, kondisi pelaku sendiri yang mengidap penyakit kelainan seksual yang biasa disebut dengan "Pedhofilia " dan sebagainya.

Faktor-faktor internal dalam diri pelaku perkosaan terhadap anak di bawah umur merupakan faktor yang juga sangat berperan penting. Faktor-faktor ini tidak dapat diabaikan begitu saja mengingat faktor-faktor ini menyebabkan kejahatan perkosaan terhadap anak di bawah umur terus terjadi.

Menurut Henri Putranto faktor-faktor internal pelaku tersebut adalah :

1. Dalam dunia kesehatan pada khususnya kesehatan reproduksi mengenal apa yang disebut "Pedhofilia ", yaitu suatu prilaku seksual dimana ketertarikan seksual diarahkan pada anak-anak, sedang orang yang melakukannya disebut pedhofil.

2. Budaya superioritas yang membuat orang merasa kuat dan ingin menguasai orang lain, orang lain dianggap sub ordinansi dan tidak salah jika dia memaksa kehendaknya pada orang lain. Kasus yang sering terjadi adalah kasus perkosaan yang dilakukan oleh seseorang yang lebih tua kepada orang yang lebih muda, misalnya: ayah terhadap anak kandungnya, kakak terhadap adiknya, kakek terhadap cucunya sendiri atau tetangganya, dan sebagainya. Posisi sosial yang menghasilkan kekuatan atau superioritas di masyarakat dalam hal ini sering juga kontribusi mengapa kasus perkosaan sering terjadi di masyarakat.

3. Moral Hazart yang tumbuh di masyarakat kian lama kian meningkat. Seseorang sudah tidak peduli apakah tindakan tersebut akan membuat korbannya menjadi menderita atau tidak. Dan yang paling esensi adalah seseorang sudah tidak peduli lagi apakah perbuatannya tersebut berdosa atau tidak

Sementara itu, Faktor external pelaku tersebut seperti :

1. Tempat, Lingkungan dimana korban (anak) dan pelaku sangat berpengaruh terhadap terjadinya kejahatan perkosaan biasanya 
pelaku perkosaan tidak mempunyai niat untuk memperkosa korban, akan tetapi karena korban berada pada tempat-tempat yang sepi atau gelap atau karena faktor kamar tidur yang tidak memiliki pembatasan dan ditambah dengan faktor kesempatan, maka kemungkinan besar terjadi perkosaan.

2. Waktu, Praduga kita bahwa perkosaan hanya terjadi pada waktu malam hari atau pada saat sepi telah ditepiskan dengan suatu kenyataan baru bahwa pada kasus perkosaan terhadap anak di bawah umur, perkosaan dapat juga terjadi pada waktu siang hari dimana anak (korban) sedang bermain atau berada di rumah sendirian. Kondisi ini dimanfaatkan oleh pelaku untuk memanfaatkan keluguan sang anak dengan menggunakan ancaman kekerasan atau bujukan.

3. Pornografi, Pornografi terbagi atas dua bagian yaitu pornografi cetak terdiri dari buku-buku porno, majalah porno, dan pornografi elektronik yang terdiri dari film-film yang berisikan adegan seks yang semuanya mengekspos/ menampilkan gambar-gambar yang dapat menimbulkan nafsu birahi bagi setiap yang melihatnya. Maraknya atau penyewaan video compat disk porno dengan bebas akhir-akhir ini turut meracuni jiwa dan moral masyarakat.

4. Alkoholisme, Alkohol dapat merusak jiwa seseorang sehingga orang tersebut tidak dapat mengontrol dirinya atau menyebabkan hilangnya daya menahan diri. Dalam kondisi yang mabuk dan keinginan seks yang tak tertahankan ini, tidak jarang anak yang masih dibawah umur dipakai sebagai tempat pelampiasan nafsu.

Selain faktor-faktor internal dan ekternal baik dari pihak pelaku maupun pihak korban seperti yang diterangkan di atas, ada satu faktor yang tidak kalah pentingnya yakni, faktor kesempatan. Walaupun faktor internal maupun faktor ekternal yang dimiliki pihak korban dan pihak pelaku begitu besar akan tetapi tanpa adanya kesempatan, maka kejahatan perkosaan terhadap anak dibawah umur tidak dapat terjadi.

\subsection{Upaya perlindungan hukum terhadap anak yang menjadi korban kejahatan perkosaan}

Perlindungan hukum tentunya tidak lepas dari perlindungan Hak Asasi Manusia, baik individu maupun bagi semua manusia secara keseluruhan. Hak asasi manusia merupakan hak dasar yang secara kodrati melekat pada diri manusia, bersifat universal dan dianugrahkan oleh Tuhan Yang Maha Esa. Oleh karena itu hak asasi yang dimiliki oleh manusia wajib dihormati, dilindungi, dan dipertahankan. Pelanggaran 
atas Hak Asasi Manusia berarti suatu pelanggaran yang sangat besar terutama dalam kaitannya dengan harkat dan martabat manusia.

Dalam Pasal 1 Deklarasi Hak Asasi Manusia (DUHAM) yang oleh bangsa-bangsa di dunia disepakati pada tanggl 10 septamber 48 dinyatakan bahwa "semua orang dilahirkan merdeka dan mempunyai martabat dan hak- hak yang sama. Mereka dikarunai akal dan hatinurani dan kehendaknya bergaul satu sama lain dalam semangat persaudaraan". Deklarasi ini mengumandangkan Hak Asasi Manusia (HAM) yang merupakan suatu hak yang meletak pada diri manusia, yang bersifat sangat mendasar dan mutlak diperlukan agar manusia dapat berkembang sesuai dengan bakat, cita-cita dan martabatnya.

Arief (1996: 53) mengemukakan bahwa masalah perlindungan korban kejahatan merupakan bagian dari masalah perlindungan hak asasi manusia. Memang ada keterkaitan erat antara keduanya, karena seperti yang dinyatakan oleh Zonimir-Paul-Seporovic "the right of the victim are a componen of the concept of human rights" (hak korban adalah komponen dari konsep hak asasi manusia).

Menurut "The declaration of basic Principies of Justice For victims of crime and abuse of power", Perserikatan Bangsa-Bangsa (1985), yang dimaksud dengan korban (victim) adalah orang-orang yang secara individual atau kolektif, telah mengalami penderitaan, meliputi penderitaan fisik dan mental, penderitaan emosi, kerugian ekonomis atau pengurangan substansi hak-hak asasi.(Arif Gosita, 1993;46).

Dengan demikian pengertian korban dirumuskan sebagai manusia yang mengalami penderitaan akibat perbuatan jahat orang lain. Penderitaan ini tidak hanya berdampak dalam kehidupan korban (anak) saja melainkan secara tidak langsung juga membawa dampak kepada kehidupan keluarga korban, masyarakat dan negara dimana korban berada.

Kejahatan perkosaan dapat juga dialami oleh anak-anak yang tergolong usia muda (dibawah umur). Pada anak-anak, sifat lugu dari seorang anak kecil yang belum dapat memprediksi kecenderungan suatu prilaku akan mempermudah terjadinya kejahatan perkosaan. Anak 
yang masih sangat tergantung secara ekonomis maupun secara social dangan orang dewasa tidak jarang dijadikan tempat pelampiasan nafsu.

Dalam Kitab Undang-Undang Hukum Pidana (KUHP), kekerasan seksual atau perkosaan terhadap anak dibawah umur dijerat dengan menggunakan pasal 287 ayat (1) yang berbunyi :

"Barangsiapa bersetubuh dengan seorang wanita diluar perkawinan, padahal diketahuinya atau sapatutnya harus diduganya bahwa umurnya belum lima belas tahun, atau kalau umurnya tidak jelas, bahwa belum waktunya untuk dikawin, diancam dengan pidana penjara paling lama Sembilan bulan".

Menurut kepentingan hukum yang berpedoman pada asas persamaan kedudukan dalam hukum (equality before the law), dapat ditarik suatu pengertian bahwa anak berhak untuk mendapatkan persamaan dihadapan hukum dan perlindungan hukum atas hak-hak dan kewajiban asasinya sama dengan warga Negara yang lainnya. Walaupun dari segi usia, anak dianggap sebagai warga Negara yang belum dapat bertanggung jawab, akan tetapi hal ini tidak dijadikan dasar mengurangi hak seorang anak untuk mendapatkan perlindungan hukum.

Dalam mukadimah konvensi tersebut dijelaskan lebih lanjut bahwa "Anak karena ketidakmatangan jasmani dan mentalnya, memerlukan pengamanan dan pemeliharaan khusus termasuk perlindungan hukum yang layak sebelum dan sesudah kelahiran". Asuhan anak pertamatama dan terutama menjadi kewajiban dan tanggung jawab orangtua di lingkungan keluarga, akan tetapi demi kepentingan kelangsungan tata social maupun untuk kepentingan anak itu sendiri, maka sudah menjadi kewajiban bagi setiap kita untuk menjamin, memelihara dan mengamankan kepentingan anak, Pemeliharaan, jaminan dan pengamanan anak selayaknya juga berada di bawah pengawasan dan bimbingan Negara, dan bilamana perlu, oleh Negara sendiri.

Pasal 1 Undang-Undang Republik Indonesia Nomor 4 tahun 1979 Tentang Kesejahteraan Anak, ditentukan bahwa anak adalah seseorang yang belum mencapai umur 21 tahun dan belum pernah kawin ( Pasal 1 angka 2. Sedangkan dalam Pasal 2 Bab II mengatur hak-hak anak yaitu :

1. Anak berhak atas kesejahteraan, perawatan, asuhan dan bimbingan berdasarkan kasih sayang baik dalam keluarganya 
maupun di dalam asuhan khusus untuk tumbuh dan berkembang dengan wajar;

2. Anak berhak atas pelayanan untuk mengembangkan kemampuan dan kehidupan sosialnya, sesuai dengan kebudayaan dan kepribadian bangsa, untuk menjadi warga Negara yang baik dan berguna.

3. Anak berhak atas pemeliharaan dan perlindungan, baik semasa dalam kandungan maupun sesudah dilahirkan.

4. Anak berhak atas perlindungan terhadap lingkungan hidup yang dapat membahayakan atau menghambat pertumbuhan dan perkembangannya dengan wajar. (Shanty, 1988; 48).

Perlindungan hukum di bedakan menjadi 2 (dua) yaitu perlindungan yang bersifat preventif dan perlindungan hukum yang bersifat refresif.

1. Perlindungan hukum yang bersifat preventif

Berupa perlindungan atau pencegahan dari segala tindakan sewenang-wenang yang dilakukan oleh manusia serta diberikan kesempatan untuk menjaga diri baik secara sendiri-sendiri maupun secara bersama-sama untuk mempertahankan hidup dan kehidupan dalam masyarakat. Sekalipun kejahatan perkosaan terhadap anak di bawah umur tidak dapat dengan mudah di lenyapkan dalam masyarakat, akan tetapi harus ada upaya-upaya yang di lakukan untuk menekan dan mengontrol sehingga tragedi kemanusiaan ini dapat di minimalkan. Kejahatan perkosaan ini harus dicegah dengan berbagai upaya perlindungan, baik yang beraspek hukum maupun yang bersifat social ekonomi. Upaya perlindungan ini meliputi perlindungan mental, fisik dan sosial anak.

Banyak kegiatan dan program yang dapat di laksanakan oleh berbagai pihak sebagai upaya untuk menanggulangi atau mencegah terjadinya kejahatan perkosaan terhadap anak di bawah umur. Salah satu usaha yang dapat dilakukan adalah dengan menegakkan hukum degan cara pemberian sanksi pidana yang tepat kepada pelaku perkosaan.

Sesuai dengan prinsip perlindungan korban di atas, terdapat 2 (dua) hal yang penting yang dapat dijadikan prinsip perlindungan hukum terhadap anak yang menjadi korban kejahatan perkosaan, yakni pertama bahwa anak yang menjadi korban perkosaan berhak 
diperlakukan secara mausiawi dan degan rasa hormat untuk martabat manusia mereka dan yang kedua bahwa anak yang menjadi korban perkosaan berhak atas ganti kerugian untuk penderitaan yang mereka sudah derita.

2. Perlindungan hukum yang bersifat Represif.

Memberikan perlindungan hukum terhadap anak yang menjadi korban perkosaan merupakan salah satu langkah penting yang harus diambil guna mencegah agar pelaku kejahatan perkosaan terhadap anak di bawah umur tidak terlepas dari tanggung jawab atas perbuatannya dan anak yang menjadi korban dapat terlindungi haknya sehingga keadilan benar-benar ditegakkan.

Ada beberapa langkah represif (penanggulangan) yang dapat dilaksanakan guna melindungi anak yang menjadi korban kejahatan perkosaan, yakni : Penegakan Hukum.

Sebagai konsekuensi dari perbuatannya maka seorang pelaku kejahatan perkosaan terhadap anak di bawah umur tidak dapat lepas dari hukuman. Penegakan hukum melalui penerapan sanksi piana (pemidanaan) yang sesuai merupakan salah satu bagian dari upaya penanggulangan kejahatan perkosaan di bawah umur.

Pasal 287 ayat (1) KUHP, tentang persetubuhan (baca : perkosaan) dengan anak di bawah umur, hanya mengatur ancaman hukuman penjara maksimal 9 (sembilan) tahun. Sanksi pidana ini begitu ringan jika dibandingkan dengan beberapa Negara di dunia. Ancaman hukuman pidana terhadap pelaku kejahatan perkosaan anak dibawah umur di Negara Indonesia berdasarkan kitab UndangUndang Hukm Pidana (KUHP), dinilai tidk menceminkan keadilan. Ancaman hukuman ini tidak sebanding dengan akibat yang diderita korban (anak) setelah kejadian perkosaan. Anak harus menanggung aib perkosaan seumur hidupnya, mengalami trauma-trauma yang selalu membuat anak merasa takut, dan atau pertumbuhan mental dan sosial anak akan terhambat; sementara pelaku hanya dituntut hukuman yang ringan.

Hillary Clinton (1996;42) berpendapat, bahwa gagalnya Pasal 287 KUHP dalam memberikan perlindungan hukum 
kepada korban perkosaan dibawah umur disebabkan karena KUHP ini sejak lahirnya pada tahun 1981 sampai sekarang belum pernah mengalami perubahan. KUHP dapat dikatakan sudah tidak efisien lagi dalam penerapannya di masyarakat mengingat bahwa msyarakat terus bertumbuh sehingga kejahatan semakin komplek dan beragam.

Berdasarkan lex spesialis derogate lex generalis, Pasal 81 (2) Undang-Undang Republik Indonesia Nomor 35 Tahun 2014 Tentang Perubahan Atas Undang-Undang Nomor 23 Tahun 2002 Tentang Perlindungan Anak mengesampingkan Pasal 287 KUHP. Pasal 81 (2) ini berisi perlindungan hukum kepada anak korban perkosaan. Dalam pasal 81 (2) Undang-Undang Republik Indonesia Nomor 35 Tahun 2014 Tentang Perubahan Atas Undang-Undang Nomor 23 Tahun 2002 Tentang Perlindungan Anak telah digunakan batas minimal hukuman penjara yakni 3 (tiga) tahun kepada pelaku kejahatan perkosaan terhadap anak dibawah umur. Jika dibandingkan dengan Pasal 287 ayat (1) KUHP, Pasal 81 (2) Undang-Undang Republik Indonesia Nomor 35 Tahun 2014 Tentang Perubahan Atas Undang-Undang Nomor 23 Tahun 2002 Tentang Perlindungan Anak ini sudah dapat dinyatakan lebih baik dan lebih memperhatikan kepentingan perlindungan korban, khususnya anak yang menjadi korban perkosaan. Dalam Pasal 81 (2) Undang-Undang Republik Indonesia Nomor 35 Tahun 2014 Tentang Perubahan Atas UndangUndang Nomor 23 Tahun 2002 Tentang Perlindungan Anak ini juga digunakan batas maksimal hukuman penjara yakni 15 (lima belas) tahun. Batas maksimal hukuman ini lebih tinggi jika dibandingkan dengan batas maksimal hukuman pada Pasal 287 ayat (1) KUHP yang hanya mengancam maksimal hukuman penjara kepada pelaku kejahatan perkosaan terhadap anak dibawah umur selama 9 (Sembilan) tahun. 


\subsection{Penerapan Sanksi Pidana bagi pelaku kejahatan pemerkosaan terhadap anak di bawah umur dalam Peradilan Anak}

Hakim dalam menjatuhkan putusan pemidanaan terlebih dahulu akan memberikan pertimbangan-pertimbangan yang akan dijadikan dasar dan pijakan dalam membuat suatu putusan. Hakim akan menelaah terlebih dahulu tentang kebenaran peristiwa, kemudian memberikan penilaian serta menghubungkan dengan hukum yang sesuai, dengan harapan dapat memberikan suatu putusan yang mencerminkan rasa keadilan yang dapat dipertanggung-jawabkan kepada diri sendiri, kepada masyarakat, dan kepada TuhanYang Maha Esa.

Pertimbangan hukum yang diberikan oleh hakim dalam sebuah putusan pemidanaan harus didasarkan pada fakta-fakta yang terungkap di persidangan, dimana putusan yang dihasilkan didasarkan sekurangkurangnya pada dua alat bukti yang sah, serta dari keyakinan hakim dalam memutus perkara tersebut. Hakim tidak boleh menjatuhkan pidana kepada seorang kecuali apabila dengan sekurang-kurangnya dua alat bukti yang sah ia memperoleh keyakinan bahwa suatu tindak pidana benar-benar terjadi dan bahwa terdakwalah yang bersalah melakukannya.

Pertama, alat bukti. Alat bukti yang di anggap sah yang akan di jadikan sebagai bahan pertimbangan bagi majelis hakim dalam perkara ini, yakni berlandaskan pada fakta-fakta yang terungkap persidangan berupa: (1) Keterangan Saksi, (2) Alat bukti surat, berupa Visum Et Repertum (3) Keterangan Terdakwa dalam Putusan.

Adapun alat bukti dianggap sah, di mana hal tersebut didasarkan bahwa apabila alat bukti tersebut saling dihubungkan satu sama lain terdapat kesesuaian antara keterangan saksi dan keterangan terdakwa serta alat bukti surat. Dengan mendasarkan kesesuaian tersebut, maka akan di peroleh fakta hukum yang meyakinkan bagi majelis hakim, yang selanjutnya akan di jadikan dasar dalam membuat putusan

Kedua, pertimbangan hakim. Pertimbangan hakim tentang hal-hal yang memberatkan dan meringankan bagi terdakwa. Hakim sebelum menjatuhkan putusan, maka akan terlebih dahulu memeriksa perkara pidana, dimana hakim akan berusaha mencari dan membuktikan 
kebenaran materiil berdasarkan fakta-fakta yang terungkap dalam persidangan, selain itu hakim juga akan berpegang teguh pada yang dirumuskan dalam surat dakwaan penuntut umum; Hakim dalam menjatuhkan pidana terhadap terdakwa juga sangat memperhatikan dari sifat kejahatan dan juga faktor yang melatar belakangi dari terdakwa, serta dampak sosial akibat kejahatan tersebut; dan Hakim juga akan mempertimbangan mengenai hal-hal yang memberatkan maupun yang meringankan bagi terdakwa.

Adapun hal-hal yang meringankan dan memberatkan para terdakwa dalam putusan yang di jatuhkan oleh majelis hakim. Dalam hal ini penulis akan berusaha untuk menguraikan pertimbangan tersebut yakni: (1) Hal-hal yang meringankan bagi terdakwa. Hal-Hal yang meringankan para terdakwa dalam putusan yang di jatuhkan oleh majelis hakim antara lain: (a) Terdakwa menyesali perbuatannya dan berjanji tidak akan mengulangi lagi perbuatanya. Penyesalan yang dilakukan oleh terdakwa atas perbuatannya, merupakan sebagai wujud keinginan untuk kembali menjadi pribadi yang benar, dimana terdakwa menyadari akan perbuatannya, dan ingin menjadikan hukuman tersebut sebagai penyesalan dengan wujud pembelajaran untuk memperbaiki diri, serta tidak mengulangi perbuatannya lagi; (b) Terdakwa berterus-terang dan bersikap sopan

Selanjutnya untuk yang kedua, hal-hal yang memberatkan para terdakwa dalam putusan yang dijatuhkan oleh majelis hakim antara lain: (a) Perbuatan terdakwa meresahkan masyarakat, bahwa perbuatan yang dilakukan oleh terdakwa telah menyebabkan keresahan dan ketakutan bagi masyarakat, sehingga perlu adanya ketegasan dari aparat penegak hukum, dalam hal ini majelis hakim untuk menjatuhkan hukuman yang setimpal, agar hukuman tersebut mampu menjadikan pembelajaran khususnya bagi terdakwa, dan masyarakat pada umumnya, sehingga penjatuhan hukuman tersebut dianggap sesuai; (b) Perbuatan terdakwa merusak masa depan saksi korban., perbuatan terdakwa bisa dikatakan sebagai perbuatan yang telah merampas hak asasi manusia, yaitu hak untuk hidup dan hak untuk tidak disiksa. Dengan demikian tindak pidana yang di lakukan oleh para terdakwa di anggap 
sebagai perbuatan yang tidak berperikemanusiaan. Dalam hal ini, terdakwa tidak pernah memperhitungkan bagaimana akibat yang akan terjadi dengan korban, dalam hal ini kerugian yang timbul bagi korban, baik dari segi moril maupun materiil. Dengan demikian, penjatuhan hukuman oleh hakim terhadap para terdakwa dianggap sebagai suatu bentuk agar menciptakan keadilan.

Dengan demikian dapat ditarik kesimpulan bahwa tujuan hakim dalam menjatuhkan sanksi pidana adalah untuk memperbaiki terdakwa agar tidak mengulangi lagi perbuatannya tersebut. Pemberian sanksi pidana dengan menimbulkan efek jera bagi pelaku berupa kepastian hukum, dengan memberikan pertimbangan dari segi pelaku berupa motif dan tujuan pelaku dalam melakukan tindak pidana tersebut. sedangkan dari segi korban berupa penderitaan yang dialami korban, serta memberikan nasehat bagi terdakwa selama dalam proses persidangan, dengan tujuan agar terdakwa menyadari perbuatannya dan diharapkan dapat menjadi pembelajaran bagi masyarakat umum.

\section{KESIMPULAN}

Keberadaan peraturan perundang-undangan yang mengatur mengenai kejahatan pemerkosaan, baik dalam KUHP maupan dalam ketentuan peraturan lain yang lebih khusus, seperti dalam Undang-Undang Perlindungan Anak, adalah untuk melindungi keberadaan anak dari segala bentuk tindak kejahatan pemerkosaan. Upaya pemberian sanksi hukuman tambahan bagi pelaku kejahatan pemerkosaan terhadap anak juga telah diberlakukan dengan dikeluarkannya Perppu tentang hukuman kebiri, tujuannya adalah untuk memberikan efek jera bagi pelaku kejahatan pemerkosaan terhadap anak yang masih di bawah umur. Kedua, penerapan hukum oleh hakim dalam menjatuhkan putusan perkara tindak pidana pemerkosaan terhadap anak yang masih di bawah umur, adalah dengan mencari dan membuktikan kebenaran materiil berdasarkan fakta-fakta yang terungkap dalam persidangan, serta hakim akan berpegang teguh pada yang dirumuskan dalam surat dakwaan penuntut umum. 


\section{DAFTAR PUSTAKA}

\section{A. Buku-buku}

Arief Gosita,1993, Masalah Korban Kejahatan, Akademika Pressindo, Jakarta

Arief, Barda Nawawi, 1996, Kebijakan legislatif Dalam Penanggulangan Kejahatan Dengan Pidana Penjara, Badan Penerbit Universitas Diponegoro, Semarang.

Darwan, Mms. 1997. Hukum Indonesia.Anak PT.Citra Aditya Banti. Bandung.

Darmawan, M.K, 1994, Strategi Pencegahan Kejahatan, Citra Aditya Bakti, Bandung.

J.E.Sahetapy. 1991.Bunga Rampai Viktimisasi, PT. Eresco,Bandung.

Shanty Lenyana, 1998. Wanita dan Anak di Mata Hukum, Liberty.Yogyakarta

\section{B. Peraturan Perundang-Undangan}

Undang-Undang Dasar Negara Republik Indonesia Tahun 1945.

Kitab Undang-Undang Hukum Pidana (KUHP).

Undang-Undang Republik Indonesia Nomor 4 Tahun 1979 Tentang Kesejahteraan Anak

Undang-Undang Republik Indonesia Nomor 39 Tahun 1999 Tentang Hak Asasi Manusia

Undang-Undang Republik Indonesia Nomor 35 Tahun 2014 Tentang Perubahan Atas Undang-Undang Nomor 23 Tahun 2002 Tentang Perlindungan Anak 